\title{
BRIGA NO BECO: UMA POESIA ADELIANA
}

\section{BRIgA No BeCO: A POEM BY AdELIA PRADO}

\author{
Leila Cristina Fajardo Nicolitto*
}

Resumo: A finalidade deste trabalho é evidenciar, nas figuras adelianas, aspectos que possam caracterizá-las como influências sociais e religiosas de todos os tempos. A partir da análise de seu poema Briga no Beco que se encontra no livro Poesia Reunida (2001) verifica-se que a situação particular vivida pela autora em sua condição de mulher e a aproximação com o universo religioso marca de forma decisiva seu discurso, influenciando tanto a escolha dos termos como sua linguagem poética, e ainda a própria valorização estética de sua obra. Além disso, acreditamos que as figuras femininas têm algo a dizer como instrumento de análise literária, podendo auxiliar na compreensão de muitos aspectos existentes em sua obra, principalmente naquelas que mostram uma psicologia estrutural alicerçada e modificada com as décadas. Este estudo fornece importantes bases descritivas e interpretativas, todas elas plenamente possíveis de enriquecer o âmbito da análise.

Palavras-chave: Adélia Prado; poesia; mulheres; literatura brasileira; religião; feminismo.

AвSTRACT: The aim of this study is to evidence, in Adélia Prado's female characters, aspects that can characterize them as social and religious influences of all decades. Analyzing her poem Briga no Beco in Poesia Reunida (2001) it becomes evident the particular situation lived by the author as a woman and how the proximity with the religious universe marks her discourse, influencing both the choice of terms and her poetical language, and the aesthetics valorization of her literary composition. Furthermore, we believe that female figures have something to say as an instrument of literary analysis, helping the comprehension of many aspects in her literary composition, mainly in those that show a structural psychology modified and consolidated over the decades. This study provides important descriptive and interpretative basis, all of them can to enrich the analysis.

KeYwords: Adélia Prado; poetry; women; Brazilian literature; religion; feminism.

\footnotetext{
"Mestrado em letras - Teoria da literatura comparada. UNESP. E-mail: leilanicolitto@yahoo.com.br.
} 


\section{CONSIDERAÇÕES INICIAIS}

Quando Adélia Luzia Prado de Freitas conheceu a poesia, considerou-a um fenômeno. Sentia-se cumprindo a sua sina, carregando a sua bandeira através da graça que havia recebido. É essa a sua preciosa bagagem. A letra é sua, a mensagem é de Deus. Jesus é Jonathan, afirma ela em entrevista dada a Cadernos de Literatura Brasileira (2000).

Cresceu e se multiplicou em vários livros, colocando neles alegrias e medos, misturando o profano ao religioso na revelação de suas mais profundas angústias e até depressões. Em cada poema lê-se a mulher, esta que é social, religiosa, profana, com sua vida que escorre pelos dedos através de suas palavras. É Eva, é Maria, é Lilith; mulher oprimida, reprimida, livre, oferece e mostra um caminho.

Ela cresce e com ela crescem seus poemas e romances. Sua produção integral relaciona-se à Bíblia, mostra no íntimo a história e o sofrimento dessas mulheres que social e religiosamente, não por Cristo, mas pela humanidade, sofreram e sofrem grandes injustiças e sofrimentos de corpo e de alma. Seus poemas são visões do mistério da fé, já que atribui a Deus a sua escrita. Por isso, é considerada muitas vezes poetisa menor.

No lançamento de seu primeiro livro Bagagem (1976), no Rio de Janeiro, estiveram presentes: Antonio Houaiss, Raquel Jardim, Carlos Drummond de Andrade, Clarice Lispector, Juscelino Kubistchek, Affonso Romano de Sant'Anna, Nélida Piñon e Alphonsus de Guimaraens Filho.

Adélia Prado começou a ser estudada no exterior. Ann Carter apresentou o primeiro estudo sobre a obra adeliana no Department of Comparative Literature, da Princeton University (EUA-1980). Nesse mesmo ano, Adélia Prado publicou o romance Cacos para um vitral.

O espetáculo Dona doida: um interlúdio estreou no teatro Delfin (RJ), em 1987. É baseado nas obras: Bagagem, O coração disparado, Terra de Santa Cruz, Solte os cachorros, Os componentes da banda e O Pelicano, este último publicado no ano da apresentação da peça. A montagem teve como protagonista Fernanda Montenegro e foi dirigida por Naum Alves de Souza. Percorreria então diversos estados brasileiros, além de EUA, Itália e Portugal.

Ainda, Fernanda Montenegro encenou Fedra em São Paulo, peça em que ambas, Adélia e Fernanda, trabalharam em torno do feminino e da religiosidade. Três anos depois do primeiro encontro é que a peça foi encenada. Deu-se o mesmo com Dona doida. Adélia dirigia-se, então, para o grande público.

Em entrevista dada a Cadernos de Literatura Brasileira (junho/2000), Adélia afirma gostar de dar entrevistas, mas para ela esse processo de concessão está ligado à dor, pois não se sente à vontade ao falar de si e de seus escritos; e o ficar frente a frente com pessoas as quais não conhece gera nela um processo que se assemelha à dor. Ao mesmo tempo, afirma ela, é bom falar e mostrar um pouco de sua pessoa e de sua escrita, como uma satisfação oferecida aos seus leitores. E ainda, todo esse processo (entrevista - dor - satisfação) relaciona-se com a Bíblia que mostra o desconforto e sofrimento, como o de Maria (alegria e dor encontram-se intimamente ligados no nascimento e morte de 
Cristo), pois dentro dos sentimentos marianos encontram-se a representação do sentimento de muitas mulheres ainda hoje no mundo.

Os recursos para a sua escrita são buscados dentro da necessidade da experiência de vivenciar o mundo. À sua poesia atribui-se caráter melancólico, como a tristeza familiar que se encontra relacionada à época da Quaresma, a qual oferece emoções fortes como amar e servir a Deus. É uma emoção ligada ao plano religioso; é a fé que se concretiza com os sentimentos presentes e aguçados das festas religiosas. A Quaresma é considerada uma época de grande reflexão para os católicos, e fica muito mais ligada, na mentalidade do povo, à morte do que a vida.

Poesia, então, passa a ser dádiva e sua crença cristã vocaciona-a para o real dentro do plano humanístico-cristão da população. Isto não implica em sofrimento, nem em masoquismo, mas constata que há dor na condição de ser e estar humano. Pecado e dor caminham paralelamente dentro da existência humana, e estão intimamente ligados a Cristo, que apresentou sua paixão e morte com um corpo carnal.

Para ela, o poema é um indivíduo e necessita de atenção, e algumas vezes de reparo. Estabelece a poesia relação com o poeta, pois este está em estado de graça. Sua poesia cotidiana se entrelaça ao trabalho de outras mulheres, além de falar algo que se estenda às pessoas. Escreve de forma muito simples, utiliza um "caderninho" porque ainda não se adaptou ao computador.

Se parasse de escrever, para ela, seria a morte!

\section{AdÉlia Mulher}

Adélia casou-se e parou de lecionar. Teve cinco filhos. Seu primeiro poema aconteceu após a morte da mãe; estava com aproximadamente quatorze anos de idade. Ficou então, responsável pelos irmãos e a poesia, esta, só se concretizou em 1972 quando o pai desapareceu. E em suas leituras, a Bíblia sempre esteve presente, desde o início.

Em sua escrita, quando começou, houve muita crítica sobre o seu novo tipo de discurso literário, inclusive e principalmente sobre seus temas que utilizavam o cotidiano e pelo fato de possuir simples vocabulário. Revela ainda seu fervor religioso e percorre o espaço entre o lírico e o irônico.

Nessa época, década de 70, o feminismo começava a despontar. Adélia parecia ultrapassada porque seus poemas tinham a interferência do religioso e muitos outros expunham a questão masculina que vigora até então.

Ela revela ainda a divindade, o humano e o cotidiano na busca da verdade, por isso seu espaço é fechado: casa, família, cidade. Explora, ainda, a mulher e o feminino, altera a tradição patriarcal cujo sistema oprime as mulheres; é um auto-retrato histórico e econômico. Dá novo tom ao ser mulher, colocando a valorização, o corpo, os gestos, afetos. É questão de amor próprio.

Ela busca a identidade com a figura ou a personagem feminina, mostrando ser livre tanto no ser quanto na experiência. A mulher se manifesta na biologia do corpo, e Deus se mostra nesse corpo através do orgasmo de suas figuras e personagens. 
Representa todas as mulheres que de uma forma ou de outra passaram e foram escritoras, muitas vezes, barradas pela sociedade, pois a literatura entrou verdadeiramente na vida das mulheres aos poucos, seja como leitoras ou escritoras. A literatura é a observação do mundo, difunde pensamentos e comportamentos. A obra feminina requer intimidade e liberdade de espírito.

\section{Adélia e Religião}

Sua confecção poética refere-se à Bíblia. Demonstra ser muito religiosa em seus escritos e em suas entrevistas. Coloca ainda anjos, igreja, corpo, salmo e oração na união da vida com Deus. O Verbo é espírito, é carne. E mostra em sua poética: cores, visões e profundezas místicas. É o seu cotidiano buscando e rumando para a lírica. Suas palavras demonstram o Ser absoluto, a perfeição divina. Não pode ser visto, mas pode ser revelado através de palavras e da espiritualidade de cada ser, de cada ato, de cada coisa.

Como sua poética é feita de metáforas, a comparamos com Tomás de Aquino e Teresa de Ávila, e usa, bem como eles, os poemas para ganhar força dentro do religioso. Sua palavra apresenta simbologia e pode ser pensada e questionada a partir disso, pois apresenta Deus como uma paixão erótica. Através de sua palavra também é possível à revelação do sofrimento e a busca dos limites da linguagem, suas significações articuladas e reais.

Para Adélia, Deus não é punidor, é amoroso, e busca a redenção assim como aparece nos evangelhos. A imagem divina surge da oração e não da teologia, da apresentação e não da tradução. É obediência como a de Maria quando da visita do anjo Gabriel, é busca do conhecimento com Eva e atitudes fortes com Ester. Deus é mais do que disseram as comunidades por meio de seus relatos e escritas bíblicas.

Também, marcada pelas mulheres, muitas bíblicas, coloca elementos poéticos como referenciais, e estes vão desde o leite até o ventre. Enfim, a poesia adeliana é a proclamação do amor, através da religiosidade e da oração.

\section{Fortuna Crítica}

A obra poética de Adélia está entre o cotidiano, o religioso e o erotismo. Para ela, a poesia é vital e ela é a escolhida para a tarefa da escrita. Ela resgata a condição feminina e o cotidiano das mulheres em seus acontecimentos domésticos, principalmente na religiosidade.

No livro Literatura e Feminismo (Ramalho, 1999) há um artigo sobre Adélia "Vivência erótica do cotidiano na poética de Adélia Prado” de Cimélio Senna que discute a influência da eroticidade nas mulheres que atuam hoje. A revista Cult (1999) apresenta uma entrevista com Adélia Prado. Nessa entrevista a poetisa fala sobre Manuscritos de Felipa e Oráculos de Maio, os livros recém lançados na época. Ainda faz observações sobre a religiosidade e o cotidiano em sua obra.

Em artigo de Elódia Xavier (2003), há observações e comentários sobre Adélia e seu livro O homem da mão seca. Elódia apresenta o livro sob os aspectos: religiosidade, carência, ligação entre os evangelhos de Marcos, Mateus e Lucas com a epígrafe do 
livro e ainda o milagre operado a ela (Adélia considera isso em relação à sua escrita) que estabelece relação com a Bíblia.

Em o jornal O Estado de S. Paulo (15/08/2000), o jornalista José Castello faz um comentário completo sobre o CD de Adélia Prado. Ele considera Adélia uma excelente intérprete, até mais que João Cabral. Também é considerada, no momento, do mesmo nível de Manoel de Barros e Hilda Hilst.

Continuando o comentário sobre a fortuna crítica de Adélia, em "Mulher e Literatura”, no Seminário Nacional Mulher e Literatura, realizado em Niterói, em 1997; há dois artigos sobre a referida poetisa. No primeiro "Memória Poética e Crítica da Ideologia em bagagem de Adélia Prado" por Angélica Soares (1999), discutem-se o discurso adeliano e a ideologia social que rege o desempenho "ideal" de mulher no sistema patriarcal. Trata, também, de uma forma superficial, sem abordagem profunda, até mesmo por ser um artigo, da formação religiosa da mulher no Brasil, bem como a permanência de estados psíquicos que são constantes nos poemas de Adélia Prado.

É uma poetisa que inspira muitos estudos, em todas as áreas que se referem aos mais diversos temas. O tema para este trabalho não apresenta muitas obras e referências para estudo, e esse é justamente o motivo pelo qual foi escolhido: mulher bíblica e social juntamente com a literatura feminina.

O texto de Adélia Prado está longe de ser simples. Sua linguagem é como matéria densa, não foi tomada de empréstimo dos homens. A verdade de sua experiência feminina completa-se com sua fidelidade à sua paisagem ambiental. Sua poesia vem do sertão.

As citações bíblicas que faz não chegam a ser uma influência, pois sua religiosidade é mais das igrejas interioranas. Ela apresenta o moderno renovado por meio de um distanciamento da necessidade de um pioneirismo pela boa poesia acima do Modernismo.

Para ela a poesia é andrógina, não tem sexo. E em relação às cores usadas em seus poemas, ela considera um aspecto material da concretude do mundo. E entre prosa e poesia, a prosa é mais laboriosa e a forma poesia dá-se o conteúdo de uma só vez.

A religiosidade de Adélia Prado revela seu ineditismo. Adélia revela a mulher provinciana cuja eroticidade só se torna conhecida por resultar de conflitos e paradoxos. Adélia supera atitudes do Modernismo, indicando a voz feminina, o interior brasileiro e a família burguesa.

O erotismo não entra em conflito com sua concepção cristã. Sagrado e Profano se misturam no mundo adeliano. Neles estão o imediato e o transcendental, o cotidiano e o sobrenatural. A voz feminina afasta a sua maneira masculina de dizer o mundo.

A poesia de Adélia Prado é intertextual. Suas principais fontes são a Bíblia (Êxodo, Salmos, Cântico dos Cânticos), Carlos Drummond de Andrade, Guimarães Rosa, Orações Religiosas, Freud, Machado de Assis, Fernando Pessoa, Contos Populares da História Antiga.

O seu processo de criação inicia-se com uma perturbação inicial, que pode vir de uma pessoa, fato ou idéia. É nessa hora que sente a necessidade de escrever. Há a perturbação 
e para ela isso é transcendência de beleza, de Deus, valores de ordem espiritual que permeiam nossa vida. A poesia de Adélia e o processo de que se utiliza para a recuperação dos resíduos de linguagem é um desejo de apreensão da poesia em si.

Partiremos agora para a etapa que se consolidará nos estudos das mulheres perante a sociedade, como elas eram e são agora, e ainda considerando as formas de serem avaliadas e educadas pelo sistema sócio patriarcal.

\section{A Mulher e a Sociedade}

Dentro de um rito social, as mulheres geram e os homens matam. Esses são pensamentos e práticas estigmatizadas por uma sociedade notoriamente machista. E apesar de estarmos no século XXI, as mulheres apresentam um perigo negro, um mistério desconhecido e ignorado por muitos, talvez por medo e não por curiosidade.

A identidade é que caracteriza e define o ser como parte integrante do universo. As mulheres possuem sua fala, raciocínio, lógica. Essas mulheres, novas, renascem como um condor, com vontades e desejos próprios, associando sentimentos e razão; elas optam pela defesa da vida, lutam, exigem, geram e libertam-se das amarras sociais que as levam para o patriarcalismo. Soltam-se da opressão, pedindo a vez e a concessão da voz.

As mulheres conscientizadas tentam resgatar suas verdadeiras imagens, alcançando um novo desempenho social, apagando a imagem de desmoralização que sofreram e ainda sofrem. Há então o reequilíbrio da cultura.
Consideradas por Beauvoir (1953 apud Rosaldo; Lamphere, 1979) como segundo sexo, temos hoje a perspicácia e a audácia de podermos alterar isto. É importante que aprendamos a ser mulheres, deixar de lado todo estereótipo aplicado pelo social às mulheres. Geralmente somos objetos, mães devotadas, esposas obedientes. O que não se pode negar é que há diferença social e política entre os sexos.

A questão familiar determina a vida social. Ao menino, requer-se o entrosamento social; à menina, compreender e ser amável. A mãe é quem determina a psicologia ora masculina, ora feminina. As mulheres reconhecem sua maturidade sendo educada e compreensível, o homem colocando sua autoridade. Dessa forma, a relação da mulher com o homem é que delimita o status que ela pode alcançar socialmente, tendo em vista que é o homem quem domina o ambiente social e esse status depende dele, de suas considerações.

Já no desenvolvimento sexual, a menina diferencia-se do menino. As atividades femininas identificam-se com as mulheres, especialmente as mães, pois o menino tem o pai distanciado, o qual cobra atitudes masculinas como revidar brigas, não chorar, ligar-se afetivamente a uma só pessoa. Isso implica em afetividade, pois a menina sempre teve relações afetivas com a mãe. É como se fosse um vínculo eterno e com a infância. E dentro do papel sexual, encontra-se o inconsciente, pois as mulheres relacionam-se com a afetividade. Em muitas sociedades a menina ora está com a mãe ora com parentes, sempre cuidada e considerada como pequenas 
mulheres. Observemos que o mesmo não ocorre com o menino.

O desenvolvimento do papel sexual da menina complica-se na modernidade; a tecnologia e a escola estão à sua disposição, porém o papel de esposa-mãe remete a uma cobrança social ainda muito forte. Enquanto as mulheres passam por essa implicação, o menino pode retirar-se e ter um autodesenvolvimento, juntando-se a outros, sem envolvimento com o mundo familiar e adulto.

Isto já faz com que os meninos não se vinculem tão forte e afetivamente quanto as meninas. Elas, em contraponto, são obrigadas a relacionarem-se com a família, possuírem vínculo e negarem o envolvimento com os garotos, o que não acontece com os meninos. Os meninos buscam a atuação e as meninas a comunidade; seria então uma socialização de personalidades. Segundo nos diz Gutmann (1965 apud Rosaldo; Lamphere, 1979, p. 56), alocêntrico ao participar de uma organização social e autocêntrico buscando vínculos afetivos.

Já para Cohen (1969 apud Rosaldo; Lamphere, 1979, p. 90), as meninas misturam os modelos cognitivos: analítico (orientação ao real) e relacional (relação ao seu contexto social). Isto implica nas mulheres, mais tarde, a confusão entre os dois tipos de funcionamento, revelando dessa forma conflitos internos, pois assim a socialização feminina assegura personalidade à mulher. O não social vivido pela mulher através das gerações faz com que se propague essa dificuldade de identificação própria: identidade e personalidade.
Dentro da psicologia feminina que se encontra estreitamente ligada ao social, as mulheres acabam por serem vítimas de si mesmas, pensam e agem conforme o sistema que apresenta e dita normas. Segundo Beauvoir (1953), citado por Ortner (1979, p. 103), "a mulher muito mais do que o homem é a vítima das espécies". A biologia feminina está ligada à procriação e as mulheres, muitas vezes, sentem-se destinadas somente a esse campo. O homem não tem essa ligação de gerar, apenas encontra-se conectado à artificialidade e à tecnologia. Suas criações são elementos técnicos, pertencentes à prática social vivenciada e cobrada até então; já as mulheres geram humanos e nunca experimentaram tais práticas, talvez por não lhes ser permitido.

Sendo ligada ao natural, possui consciência igual a do homem. Faz parte de uma raça e é importante nesse processo cultural, pois seres humanos completam-se, pensam e falam. A consciência feminina a esta altura já está envolvida culturalmente, seja com sua aceitação ou desvalorização. É comum ouvirmos de mulheres, que sendo homem, tudo pode, e para a mulher as coisas são assim mesmo. Existe um conformismo aplicado ao cotidiano feminino para justificar muitas coisas que acontecem, como por exemplo, o estupro, no qual se julga muitas vezes que as mulheres os provocaram. Na cultura as mulheres raramente têm razão, e isso é, muitas vezes, aceito e compartilhado por elas.

Ainda segundo Ortner (1979), as mulheres possuem um montante de diferenças em relação aos homens, passam então a ser mais rigorosas que os homens. Não se trata 
de desvalorização, mas de restrição cultural, controle. Não se pode negar que elas são intermediárias e que ambos possuem criatividade, o que pode representar o progresso da cultura com e não em relação à natureza. Uma vez que o mundo doméstico pertence às mulheres e o político aos homens, a vida familiar e social apresenta conflitos de interesse e cooperação.

Dessa forma, dá-nos a entender que a identidade feminina é construída a partir do social e do histórico e isso ajuda a manter a mulher subordinada ao homem, dando e atribuindo a ela esses caracteres como fator de natureza feminina. Trata-se de uma questão de ideologia. Mas, ainda hoje, podemos perceber essas ideologias, como nas músicas: poposudas ou Amélias, a sensualidade ou a aceitação dentro do lar. Ainda assim, as mulheres estão condicionadas a uma subjetividade imposta pelo homem.

Já o impulso do poder é indispensável ao desenvolvimento do patriarcalismo, poder este que as mulheres vêm buscando e negando sua própria condição de ter. Segundo nos afirma Whitmont (1991), a luta pelo poder já é antiga. Começou com o pré-cristianismo. O herói era o ideal. Assim, o homem foi-se tornando ideal dentro da comunidade, seguindo apenas uma tradição.

Percebemos que a desvalorização do feminino tem suas raízes em preconceitos que se tornaram destrutíveis ao desenvolvimento da consciência feminina; $e$ o fato de considerada como não possuidora de alma, a deixa frágil para pecar e, conseqüentemente leva o homem juntamente consigo. Como se ele dependesse única e exclusivamente da mulher, sem sistema de opressão. Aliás, este já é um sistema opressivo; colocar o "pecado" como exclusivo das mulheres é dar-lhes barreiras e moldar seu comportamento.

Mas surge o novo feminino após as revoluções femininas e segundo Whitmont (1991), as mulheres descobrem o valor de sua interiorização, mostram-se abertas a alegria e dores. Seu novo desafio é a própria cura, de corpo e alma. Isso se concretizará na conscientização, é o arriscar-se, mostrando que pode e deve quebrar o estereótipo antigo. Passa a ser um canal de percepções, assume sua nova realidade.

A ideologia passada pela sociedade e que se perpetua até hoje, embora com muitas reações, é que a posição do homem é mais forte socialmente do que a das mulheres. Isso afeta tanto as mulheres que mesmo dentro de uma nova década e novas visões, elas não abandonam seu estigma anterior: o de boas esposas e o da maternidade. E muitas vezes, quando fazem opção por não casar, ou não ter filhos, acabam sofrendo sérios ataques sociais, ou ainda, ficando extremamente ansiosas.

Na realidade as mulheres não deixaram, ou pelo menos não conseguiram, livrar-se totalmente do estereótipo de que a mulher é fraca, e não serve para comandar, pois seu intelecto e seu emocional são leves e frágeis, não fazendo frente a qualquer homem que seja. As mulheres passam a não se contentar com o que lhes foi ofertado, começam a exigir já que são as responsáveis pelo andamento da casa e as atividades filial e marital.

Esse problema agrava-se quando seu rendimento monetário passa a ser maior, 
ou muito maior em relação ao do marido. Instaura-se então, um descontentamento matrimonial devido à ideologia estigmatizada da sociedade de que o homem deve ser o provedor da família.

\section{A Mulher no decorrer dos Séculos}

$\mathrm{Na}$ antigüidade as mulheres eram deusas, mas o poder era dado ao homem embora se cultivasse o culto à fertilidade que está ligado ao feminino, segundo afirmam Rosaldo e Lamphere (1979). Biologicamente há diferenças, tanto na resistência física, como na questão cultural e esta demonstra claramente a desigualdade, imposta socialmente pelo homem, tornando as mulheres seres irrelevantes e dependendo do reconhecimento deste.

Mas, a partir da década de 70, as mulheres assumem o papel de trabalhadoras com direito a carreira. Muda então sua essência. Questiona toda e qualquer doutrina que fosse propagada e cobrada delas. Então, elas buscam seu novo papel na sociedade: pensam e agem por si só. A visão das mulheres se abrem, não deixando agora dominarem-se por uma ideologia.

No Brasil Colônia, também não havia problemas em relação às mulheres, do ponto de vista patriarcal, pois elas não precisavam se ausentar qualquer que fosse a atividade. O mascate era o seu elo de ligação com o mundo. E quanto mais filhos elas tivessem, mais era provada a virilidade do homem e marido. As mulheres ainda não tinham tomado consciência da exigência de sua própria identidade.
Somente no século XIX é que se abre a escola normal. Esta possibilita ao público feminino almejar uma oportunidade profissional e social dentro de uma sociedade constituída de maneira severamente machista. A situação financeira das mulheres contribuía para que elas se acomodassem muitas vezes, e não procurassem realização profissional, ainda que remota. Não lhes era necessário uma carreira, já que esta era o casamento.

Acompanhando ainda Rocha-Coutinho (1994), até o final do século XIX tanto as mulheres casadas quanto as solteiras ficavam em casa e tinham seu trabalho nesse ambiente. E com a industrialização, famílias menos abastadas permitiam que as mesmas trabalhassem nas fábricas. Um exemplo é que em São Paulo, em 1872, dos 10256 operários do algodão, 9514 eram do sexo feminino.

No século XX, as mulheres também começaram a exercer a função de vendedoras e secretárias. Em 1931, houve um inquérito de Departamento Nacional do Trabalho que afirmava que as mulheres eram indispensáveis às atividades por serem mais dóceis, pacientes e dedicadas ao serviço.

Com o final da Segunda Guerra Mundial as mulheres são chamadas a voltarem ao seu "destino biológico", deixando os lugares para serem ocupados por homens que voltavam do front de guerra. Assim, apregoava-se novamente a boa mãe no lar, e desnaturada aquela que abandonasse seus filhos, caso trabalhasse fora de casa. É mais uma forma de detenção sexo-cultural, conforme nos coloca Rocha-Coutinho (1994).

E nessa busca desenfreada pela liberdade acabam confundindo-se em muitos 
momentos da vida, não tendo consciência de seus próprios limites, só para "provar" a esta instituição denominada patriarcado que elas também são capazes.

\section{Mulher e Família}

Dentro de tantas mudanças ocorridas na estrutura sociofamiliar, o ciclo desenvolve-se sofrendo um processo de transformação social e econômica. A família em um processo de desenvolvimento tem como posição primordial o homem. A autoridade se dá com o homem e dentro de um grupo familiar; o casamento, direitos e deveres são transferidos ou criados dentro desta instituição. Muitas vezes as mulheres passam do jugo do pai para o do marido, mesmo em tempos pós-modernos.

Os direitos femininos dentro da família passam a ser apenas o trabalho doméstico, filhos e sua sexualidade, desde que convenha aos padrões pré-determinados. Tem-se em vista que as mulheres, em tese, dependem econômica e socialmente do homem. Esse controle feminino acaba por passar desapercebido, pois os meios dentro dos quais as mulheres resistem a esse controle não são discutidos.

Dentro ainda de todo esse contexto, as atitudes femininas são uma reação a essas autoridades, pois agem com persuasão. É então uma importante arma, pois se transforma em influência. Quando as mulheres induzem a uma ação ou alguém a uma decisão, mostram sua influência dentro desse contexto, assumem então o seu poder. Mas, elas só podem influenciar o homem dentro de seu centro de poder masculino e quando este as deixa, quando assume uma nova postura social e cultural que não seja o patriarcalismo. Esse rege a sociedade com regras e comportamentos conforme o sexo que se tem.

Ainda em relação à família, da feudal para a burguesa, houve muita mudança. Acentua-se a partir de então a intimidade, a individualidade, as entidades, uso de nomes e sobrenomes. Com a vinda da sociedade industrial, a individualidade se desenvolve. A prioridade da vida se reorganiza.

Forma-se então a instituição social e sacralizada: o casamento, tido por amor, transforma as relações pessoais de toda a família, pois existe aí uma relação de bem-querer que postula às mulheres em mais um sistema opressivo. Muitas vezes só elas amam e abrem mão de sua vida em nome do amor. Quantas donzelas morreram ou se resignaram em nome do amor?! Quanto aos homens não presenciamos o mesmo fato. É o que Shorter (1975 apud CHODOROW, 1979) denominou de Revolução Sentimental do Século XVIII, pois consta do aparecimento do amor materno, conjugal e a intimidade, porém, será mais uma algema para as mulheres.

A família começa a ser independente, com entradas particulares, processo este denominado de independência conjugal e afetiva; marido e mulher se assumem, não dependem mais do grande clã. Rocha-Coutinho (1994) diz que a criança passa a ser o motivo de preocupação dos pais; cria-se então a questão psicológica, tê-la e segurá-la em casa. Isso gira em torno da mulher. Ao pai cabia o sustento e o trabalho. 
O poder que é determinado sobre as mulheres, as subordina à casa, filhos e esposo. Isso implica no desprezo de suas próprias vontades, frente à realização de outras da família. Essa subordinação acaba por ser considerada natural, sem que as mulheres tomem o real conhecimento disso, pelo menos não por enquanto. Preferem não tomar consciência dessa realidade, por isso enchem de atividades domésticas o seu dia-a-dia, ou quando não, evadem-se nelas, praticando-as com perfeccionismo.

Assim como as mulheres aprendem a ser mulher, os homens aprendem a ser pai, e isso não quer dizer que eles abandonem tudo para o ser. Então, por que o projeto de vida das mulheres tem que ser mãe? O homem ainda se percebe que quer muito ser pai; quanto às mulheres já não podemos dizer o mesmo. Hoje, verifica-se uma transformação social que muda a posição das mulheres no Brasil e no mundo.

Mas é através do discurso higienista, o qual explora sua própria saúde para obtenção de atenções e regalias, que as mulheres começam a se impor para filhos e maridos, demostrando seu nervosismo como forma de lhes chamar a atenção. De acordo com Rocha-Coutinho (1994) elas mostravam isso devido ao "instinto" materno, e aquela que não o tivesse era considerada desnaturada. Dessa forma surge a válvula de escape que é a crise de nervos, que só vem a ajudar as mulheres neste momento de mais uma transição familiar dentro do sociocultural. Mantinha maridos e filhos ao seu redor para alguns deleites de companhia e atenção familiar.
Nas décadas de 60 a 70, ainda de acordo com Rocha-Coutinho (1994), o casamento assumia o papel fundamental na vida de uma moça. E esse papel se completava com o nascimento dos filhos. Quem não os pudesse ter, era digna de pena. Após o casamento, cuidava do lar ou supervisionava quem o fizesse. As mulheres então eram isoladas, não existia sua sociabilidade. Surge a depressão feminina. O valor social feminino era alcançado através do mando. Era inapropriado às mulheres ter inteligência superior, ou fazer questionamentos sobre sua posição e imposições masculinas. Muitas vezes não tinham consciência disso, pois até seu pensamento era moldado.

O casamento era visto como indissolúvel, e sua longevidade era dedicada única e exclusivamente às mulheres. Inclusive revistas da época davam dicas de como as mulheres deveriam "segurar" seus maridos e casamentos. Mas muitas delas sentiam-se descontentes com essa situação, e na educação das filhas passavam mensagens duplas: ou sugeriam a libertação ou que continuassem na maternidade.

Atualmente são muitas as mulheres responsáveis pela sua própria sexualidade, incluindo todas as conquistas feministas das últimas três décadas, porém lembremos que muitas ainda não conseguiram abandonar o modelo antigo. E ainda observamos muitas mudanças em relação ao casamento. Elas fazem opção positiva ou negativa em relação a eles, bem como ter ou não filhos, ou ainda qual a melhor época para tê-los. Agora, nada mais se resume ao social e por imposição ideológica. 
A influência se dá das mulheres para os homens quando estas os induzem a alguma decisão mostrando seu interesse. E dentro do campo profissional, quando casadas e com filhos, é bem mais difícil seu reconhecimento, pois elas continuam a serem vistas como esposas.

Dessa forma, renovação $\mathrm{x}$ tradição, entram em confronto dentro da sociedade e das famílias. Ao mesmo tempo em que as mulheres e a sociedade mudaram, permanecem, ambas, ligadas a um passado não muito distante que a impede da verdadeira mudança. Algumas mulheres e homens conseguem mudar o íntimo de seu relacionamento tendo em vista as novas propostas sociais, com respeito mútuo e de identidade. Outros, apesar da tentativa, estão presos ao molde tradicional; outros ainda nem sequer cogitam a mudança.

É muito clara toda a pressão e opressão que as mulheres vivenciaram até hoje. E ainda, foi necessário que elas utilizassem os mais variados métodos para que pudessem ter sua própria identidade. $E$ até poderíamos dizer para que pudesse ter a palavra "mulher" como sinônimo de respeito e de consideração por toda a sociedade a qual, elas ajudavam a manter. A ideologia do "machismo" e da "inferioridade mental, intelectual e corporal feminina" apenas é uma forma de controle e princípios (masculinos, é claro), ideais e detenção de poder.

\section{7- Lilith e as Mulheres Bíblicas}

A perspectiva feminina dentro da Igreja deixou a desejar desde séculos. Sempre houve alguma forma de imposição e de domínio sobre as mulheres. Percebemos isso claramente quando tratamos de sua vocação natural ao casamento e à maternidade e como foram desqualificadas pela mesma Igreja que exaltava Maria e crucificava Eva. Músicas sobre Maria há centenas, sobre Eva nenhuma. Quando citamos Igreja, falamos de sociedade católica. O sistema social vigente determinava as forças da igreja ditando normas e colocando seres masculinos e seus posicionamentos perante e sobre as mulheres. A Igreja fazia seus tais conceitos e atitudes.

Desde o século XIX as mulheres procuraram sua própria emancipação e para isso atribuiram características femininas que são modelos de personalidade. Hoje, isso já é fato. Como centro da história, recupera sua imagem desfigurada pelos séculos e pela sociedade. Com Eva chega a Queda e com Maria a redenção. Não podemos nos esquecer que a teologia mudou muito a situação feminina na Igreja e na cultura. Podemos dizer que a mulher assume uma nova postura dentro do ser e considera-se elemento ativo na construção da sociedade e da religião.

A Igreja, em muitos lugares e nas mais diversas religiões, já aceita a mulher como membro participante e atuante dentro da salvação. A mudança foi grande, mas é sempre necessário que se procure o lugar e sua função de acordo com Cristo e não simplesmente do ponto de vista religioso.

8. O Universo Feminino em Adélia Prado - "Briga No Beco"

Encontrei meu marido às três horas da tarde 
com uma loura oxidada.

Tomavam guaraná e riam, os desavergonhados.

Ataquei-os por trás com mão e palavras que nunca suspeitei conhecer.

Voaram três dentes e gritei, esmurrei-os e gritei,

gritei meu urro, a torrente dos impropérios.

Ajuntou gente, escureceu o sol,

a poeira adensou como cortina.

Ele me pegava nos braços, nas pernas, na cintura,

sem me reter, peixe-piranha, bicho pior, fêmea-ofendida, uivava.

Gritei, gritei, gritei, até a cratera exaurir-se.

Quando não pude mais fiquei rígida, as mãos na garganta dele, nós dois petrificados,

eu sem tocar o chão. Quando abri os olhos,

as mulheres abriam alas, me tocando, me pedindo graças.

Desde então faço milagres. (Prado, 2001, p. 99)

Neste poema, a figura feminina não obedece ao marido, como nos propõem os princípios religiosos e bíblicos que seria a maneira de alcançar a santificação.

Quando encontra o marido com a "outra", as relações sociais entre os sexos se rompem, ou seja, dentro de um sistema patriarcal, obediência e submissão em todas as situações. É dever da mulher ser fiel e do homem ser infiel e mostrar sua virilidade fora de casa.

As metáforas que unem ferocidade (peixe-piranha/bicho pior/fêmea ofendida/ uivava) mostram Lilith agindo nessa mulher. A irritabilidade (gritar e exaurir) demonstra que força, coragem e agressividade são qualidades opostas àquelas que identificam o universo feminino dentro da sociedade, pois o desejável é a garantia da domesticação da mulher e respeito da hierarquia patriarcal (tanto sexual quanto social), sendo a mulher o pólo negativo, capaz de causar insatisfação e preconceitos se não seguir as normas determinadas.

Em relação à domesticação da mulher, abrimos parênteses para lembrar que somente bichos devem ser domesticados. Temos aqui a assimilação pela figura feminina do que é pré-estabelecido (palavras que não conhecia e somente a raiva fez com que elas viessem à tona), tabus que querem camuflar a real situação por dependência e subordinação, por consentimento incutido dentro da identidade feminina, fato este que não ocorreu neste poema, pois a mulher se rebela com atos, palavras e ações.

O que concretiza a sua libertação momentânea foi, em um primeiro momento, o marido que possivelmente fora visto como homem perfeito segundo a sociedade patriarcal. E foi passada das mãos do pai para as do marido, o qual é livre de qualquer dúvida ou suspeita, possivelmente considerado um "deus", e capaz de realizar todas as suas necessidades materiais. E justamente por este motivo é que quando de sua agressão a ele, outras a saúdam, como se ela tivesse 
o poder, pois simboliza a mesma situação vivida pelas outras mulheres; é o self que se realiza em outra pessoa. Libertar-se das amarras da opressão masculina era o desejo, porém muitas delas não tinham coragem de fazê-lo ou de demonstrar sua força e lutar pela sua própria identidade e posição dentro desta sociedade.

Portanto, a provocação abala o sistema entre o feminino e masculino. Essa mulher constituída pelo princípio da exclusão social internaliza e torna exterior todas essas constituições. Renuncia ao papel demarcado, não se deixando oprimir por esse círculo familiar-social. Existe a conquista dessa sociedade contemporânea. Vai contra a herança da mulher judaica-cristã, vista como culpada e sendo portadora do mal para a humanidade e para os homens.

$O$ que a sociedade exige desta figura feminina, bem como a religião, é que esta aceitasse essa ordem sem se manifestar ou querer mudar a ordem das coisas. É vista pelas outras mulheres como libertadora, defendendo ou fazendo o que elas não tivessem coragem de fazer: defender-se, questionar e mudar sua situação.

Lilith aparece novamente no grito e no uivo que significam toda essa força feminina, contida dentro do psicológico e oprimida por anos, saindo de forma imprevista. A própria personagem se assusta com sua força e seus sentimentos.

Por mais força que tivesse o marido, a mulher agora se tornara o mal, que do ponto de vista religioso, ela deve rejeitar, afastando de si e de sua família o que pode causar "desgosto" e se tornar, desta forma, uma verdadeira mulher cristã, consciente de todo o seu processo de base para a sua felicidade conjugal e união com toda a família.

Ao mesmo tempo em que ela deve ser submissa perante a sociedade, é vista como força dentro do matrimônio, força essa e missão, que se fracassassem seriam vistas como defeito da própria conduta e ação femininas.

Outro ponto importante, que não deve passar despercebidamente, é o fato de que o homem pode ter matado a mulher. Os dois se pegam na garganta, mas ela não toca o chão com os pés. Talvez fosse por isto que ela tivesse sido vista como mulher que faz milagres, e para esta, as mulheres abriam alas por invejarem o seu ato.

Notando que pudesse acontecer a segunda hipótese, voltemos ao sistema social, este que atribuiu às mulheres, qualidades, porém depois de mortas. Seria preservada assim uma "canonização" para esta mulher, que se rebelou contra princípios religiosos e culturais e não podendo perder o controle da situação, lhe dá um título para que outras se apeguem no que fez, mas que não sigam o seu exemplo. Ou ainda, que se o fizerem não poderão lutar contra o sistema e força de um homem.

Mesmo com sua possível morte, ela se encontra dentro de um processo de busca de sua identidade feminina; quando dominada e fêmea, age defendendo a sua individuação como ser feminino e portador também de direitos.

\section{Considerações FinaIs}

Muito ainda se tem a abordar sobre Adélia, uma voz muito representativa da 
poesia brasileira. Adélia traz fortes reflexões sobre a sexualidade feminina.

Valoriza, no seu eu feminino, os sentidos do corpo, a identificação feminina com a religião e o mundo. Mostra que sacrifício da carne de Cristo é uma experiência carnal, e muitas vezes seus poemas retratam tabus e proibições; porém esse sentimento transforma, em seus poemas, a devoção e a adoração.

A posição da poetisa é de proponente de reflexões sobre o caráter salvador de sua poesia. Ela concretiza e humaniza Deus, diviniza o homem. Ela retrata o corpo e o sangue de Cristo como sacrifício que liga o amor e o sacrifício de Deus pelos homens.

Assim sendo, seu poema luta contra o isolamento e diferença humana que nos posicionam na sociedade como submissas, mostrando o que há de mais cotidiano, cenas comuns, corporificação para construir seus significados dentro de uma simplicidade insubstituível.

Apresenta também idéias revolucionárias, como vigorar a voz feminina, multiplicando as imagens de sexualidade e erotismo da alma. Aproxima o desejo humano à adoração divina. Busca com fonte libertadora, suas fontes de cultura regional.

Solidariedade, registro lingüístico. Ritmo, som constroem o discurso oral presente na oralidade do estilo adeliano. Com certeza, se fizéssemos só uma análise superficial da poesia de Adélia Prado, definiríamos, de forma crítica a condição feminina. O exame, ou análises mais aprofundadas, demonstram exatamente o conteúdo social da lírica, que é espontânea, universal e materializa a subjetividade.
Há a insubordinação do sujeito poético às regras sociais. Sua obra, até hoje, torna-se "desobediente" quanto mais acentuado é o grau de subjetividade em seus textos.

Sua linguagem subjetiva propicia uma identificação do público feminino com sua fala. Refletindo sobre a liberdade e a dignidade individual e universal, sua poesia é de cunho existencial e restabelece à sociedade, transformando-a na imagem que se autentica e reconhece.

E ainda a imagem de Deus, a vertente religiosa, apresenta relação entre a rítmica e a semântica; portanto formas bíblicas e oração se confundem com caráter pragmático de sua escrita. O ser se define pelo novo contexto. Quanto ao ponto de vista semântico, a poesia de cunho religioso se constrói na tradição e na ruptura.

São valores éticos e culturais que cultuam a linguagem coloquial como um modo de expressão próprio de ser. Sua linguagem, o cotidiano, a vida comunitária e familiar adquirem a essência e a descoberta do eterno na vida simples e degradada. É uma emersão do esquecimento, do tempo desdobrado e da criação.

\section{REFERÊNCIAS}

\section{ADÉLIA PRADO. Cadernos de Literatura} Brasileira, São Paulo, n. 9, jun. 2000.

BEAUVOIR, S. de. 0 segundo sexo. Fatos e Mitos. Tradução de Sérgio Milliet. Rio de Janeiro: Nova Fronteira, 1949.

BÍBLIA SAGRADA. 38. ed. São Paulo: Paulus, 2000.

CASTELLO, J. Adélia Prado retoma o diálogo com Deus em 2 livros. $\mathbf{O}$ Estado de S. Paulo, 
São Paulo, 25 mai. 1999. Disponível em: <http:// www.secrel.com.br/jpoesia/ castelo.html>. Acesso em: 20 jul. 2003.

CASTELLO, J. O incontestável poder das palavras. O Estado de S. Paulo, São Paulo, 15 ago. 2000. Disponível em: <http://www.secrel. com.br/jpoesia/castelo.html>. Acesso em: 20 jul. 2003.

CHODOROW, N. Estrutura familiar e personalidade feminina. In: ROSALDO, M. Z.; LAMPHERE, L. (Coord.). A mulher, a cultura e a sociedade. Trad. Cila Ankier e Rachel Gorensteisn. Rio de Janeiro: Paz e Terra, 1979. p. 65-90.

KOLTUV, B. B. O Livro de Lilith.. 9. ed. Trad. Rubens Rusche. São Paulo: Cultrix, 1997.

LAMPHERE, L. Estratégias, cooperação e conflito entre as mulheres em grupos domésticos. In: ROSALDO, M. Z.; LAMPHERE, L. (Coord.). A mulher, a cultura e a sociedade. Trad. Cila Ankier e Rachel Gorensteisn. Rio de Janeiro: Paz e Terra, 1979. p. 121-159.

ORTNER, S. B. Está a mulher para o homem assim como a natureza para a cultura? In: ROSALDO, M. Z.; LAMPHERE, L. (Coord.). A mulher, a cultura e a sociedade. Trad. Cila Ankier e Rachel Gorensteisn. Rio de Janeiro: Paz e Terra, 1979. p. 95-118.

ROSALDO, M. Z.; LAMPHERE, L. (Coord.). A mulher, a cultura e a sociedade.Trad. Cila Ankier e Rachel Gorenstein. Rio de Janeiro: Paz e Terra, 1979. p.56-90

A mulher, a cultura e a sociedade: uma revisão teórica. In: ; LAMPHERE, L.

(Coord.). A mulher, a cultura e a sociedade. Trad. Cila Ankier e Rachel Gorenstein. Rio de Janeiro: Paz e Terra, 1979. p. 33-60.

PRADO, A. Poesia reunida. 10. ed. São Paulo: Siciliano, 2001.
. Cult - Revista Brasileira de Literatura, São Paulo, n. 21, abr. 1999. 64 p.

Bagagem. Rio de Janeiro: Imago, 1976.

Manuscritos de Felipa. São Paulo:

Siciliano, 1999.

O homem da mão seca. São Paulo: Siciliano, 1994.

Oráculos de Maio. São Paulo: Siciliano, 1999.

QUEIROZ, V. O vazio e o pleno. A poesia de Adélia Prado. Goiânia: UFG, 1994.

O vazio e o pleno. Jornal de Poesia Online. Disponível em: <http;//www.secrel.com.br/ jpoesia/vqueiro1.html>. Acesso em: 20 jul. 2003. RAMALHO, C. (Org.). Literatura e Feminismo. Propostas teóricas e reflexões críticas. Rio de Janeiro: Elo, 1999.

ROCHA-COUTINHO, M. L. Tecendo por trás dos panos: a mulher brasileira nas relações familiares. São Paulo: Rocco, 1994.

ROSALDO, M. Z.; LAMPHERE, L. (Coord.). A mulher, a cultura e a sociedade. Trad. Cila Ankier e Rachel Gorenstein. Rio de Janeiro: Paz e Terra, 1979.

SOARES, A. Memória poética e crítica da ideologia em Bagagem, de Adélia Prado. In: Seminário Nacional Mulher e Literatura, 7. Niterói, 1997. Mulher e Literatura / Lívia de F. R., Lúcia H. V., Maria B. P. (Orgs.). Niterói, RJ: EDUFF, 1999b. (CD-ROM).

XAVIER, E. Adélia Prado. Disponível em: http://www.secrel.com.br/jpoesia/xavier15. html. Acesso em: 20 jul. 2003.

Recebido para publicação em 20 maio 2014 Aceito para publicação em 30 set. 2014. 